\title{
Understanding the Concept of Sustainable Development for Effective Solid Waste Management: Malaysia Perspective
}

\author{
Abas MA* \\ Faculty of Earth Science, University Malaysia Kelantan, Malaysia \\ *Corresponding author: Muhamad Azahar Abas, Faculty of Earth Science, University \\ Malaysia Kelantan, 17600, Jeli, Kelantan, Malaysia, Email: zaha.abas@gmail.com
}

\section{Perspective \\ Volume 1 Issue 1}

Received Date: August 28, 2018

Published Date: September 19, 2018

DOI: $10.23880 /$ oajwx-16000107

\begin{abstract}
Malaysia's economy has experience a change of dependence on the agricultural sector to the industrial sector. This rapid economic change has been supported by the phenomenon of globalization. As a result, the culture and lifestyle of Malaysian has been inclined towards consumerism. This unsustainable lifestyle has led to drastic increase of solid waste generated annually. Immersion the concept of sustainable development in solid waste management is an initiative and effective approach in addressing solid waste generated problem. Accordingly this paper discusses theintegration of solid waste management with the concept of sustainable development is scrutinized to exemplify the features and components that essential in effective solid waste management. Besides that, the concept of Integrated Solid Waste Management (ISWM) is explored to acquaint the concept of effective solid waste management. Comprehendingthe concepts and eachcomponent related to sustainable development and solid waste management could be an insight towards effective solid waste management in developing countries.
\end{abstract}

Keywords: Sustainable Development; Solid Waste Management, Integrated Solid Waste Management (ISWM); Effective Solid Waste Management

Abbreviations: ISWM: Integrated Solid Waste Management; UN: United Nations; OECD: Organisation for Economic Co-operation and Development; UNCTAD: United Nations Conferences on Trade and Development; UNCED: United Nations Conference on Environment and Development; TBL: Triple Bottom Line.

\section{Introduction}

In the last decade, the phenomenon of globalization and industrialization has greatly changed the culture and lifestyle of Malaysian. The unsustainable consumer culture among Malaysian has led to a dramatically increasing solid waste generated every year [1,2]. According to Latifah the average solid waste generated by individual that living in urban area is $1.2 \mathrm{~kg}$. Consequently, Malaysia needs more solid waste disposal sites to accommodate the solid waste generated. Ineffective and unsustainable management of solid waste disposal site will cause negative impact on environment, social and economic wellbeing [3]. In average, solid waste disposal site in Malaysia is only able to accommodate the 


\section{Open Access Journal of Waste Management \& Xenobiotics}

solid waste generated for two (2) years. This situation is dissimilar with solid waste disposal site in developed countries which able to last up to 10 years [1].

The issue of ineffective solid waste management has grabbed the attention of Malaysian Government. Therefore, various initiatives have been implemented by the Malaysian Government since 1988 through the Action Plan for Beautiful and Clean Malaysia which known as ABC Plan. In 2007, solid waste management in Malaysia has experience huge transformation when the Solid Waste and Public Cleansing Management Act (Act 672) were introduced [4]. Through this Act, solid waste management in Malaysia becomes more organized and systematic. However, implementation of this Act 672 is not as easy as expected. Application the concept of sustainable development in implementing this Act 672 could be an opportunity towards sustainable solid waste management in Malaysia.

\section{International Organisation Concern on Environmental Issues (SWM)}

In early 1942, the signing of the Atlantis Charter was aimed to facilitate the discussion that concerning the organisation in lieu to the failure of Nations League. At the end of world war, world leaders have begun to provide plans for a more secure future. According to Shulman wars and disputes between nations can be solved by discussion and cooperation [5]. Thus, the formation of the United Nations (UN) structure has been ratified by 51 countries. The UN structure was signed on 26 June 1945 and came into force on 24 October 1945 [6]. With that, the United Nations became the largest international organisation with the aim of providing a platform for dialogue and discussing issues of war misery. After half century, the United Nations has been comprised of various countries regardless of the rich or the poor and the large or small to jointly discuss and debate the idea of economic development, environmental issues, and solid waste management [5].

In conjunction of the United Nations setting up, five (5) basic themes introduced as guidelines namely international law, international security, economic development, social development, and human rights. Four (4) organisations have been formed under the UN's infrastructure as the main driving force namely Trustee Council, Security Council, International Court of Justice, and the Secretary. Each Organisation has its own goals and mission and has always been aware of current issues and needs. Environmental-related actions and waste management began to be discussed after the war era until today [5].

After the world war, economic, social and political changes occurred drastically in most countries. The Organisation for Economic Co-operation and Development (OECD) was formed in 1960 with a membership of 20 countries. The OECD serves as a free forum for democracy to devise an economic and social development strategy that involves developing countries. Consequently, 31 countries have been experts in paying attention to environmental, economic and social issues so that sustainable development strategies can be integrated into national policy [5]. The United Nations Conferences on Trade and Development (UNCTAD) Conference was held in 1964 to deal with trade, investment and development issues by supporting developing countries to engage in world economic development and to ensure that domestic and international policies nationally does not conflict with the concept of sustainable development.

In the era of globalization, the rapid development of technology and innovation has led to increased globalization of commerce. Commercialized globalization has worsened environmental issues and requires global and local solutions. Hence, United Nations Environment Programme (UNEP) and Basel Convention have been set up to assist marginalized countries to become part of the global economic development [7]. UNEP was set up in 1972 to facilitate international affairs related to the implementation of environmental policies, development of environmental-related policies, and identifying environmental impacts to the world's population. Besides that, Basel Convention was formed in 1989 under the UNEP to complement the gap existing among existing mandates with the monitoring of world trading activities to align with the sustainability objectives. Over the next 20 years, both organisations have implemented a holistic environmental awareness program for local governments, national governments, non-governmental organisations (NGOs), industries, and the public at global and local levels. Various movements and waste management strategies have been planned across borders with attention to reduce the impact of ineffective solid waste management [5].

Accordingly, the Stockholm Meeting was held in June 1972 as the preparation of the United Nations Conference on Environment and Development (UNCED). This conference was a starting point for a new era of expansion of sustainable development activities worldwide. According to Shulman, various international organisations have been set up to deal with waste and 
environmental issues (Table 1). In June 1992, UNCED was held in Rio Janeiro with the aim of forming alternative strategies and actions that could be adopted in a short, medium and long term to ensure the integration of environmental, economic and social wellbeing into account in the development process. In the context of solid waste, a conceptual framework has been formed by exploring various approaches to assess potential targets for environmental impacts. Life Cycle Assessment (LCA) has been taken as an effective approach in identifying and evaluating activities that have a negative impact on the environment and finding solutions by suggesting appropriate alternatives and options [5].

\begin{tabular}{|l|l|}
\hline \multicolumn{1}{|c|}{ International Committee } & \multicolumn{1}{|c|}{ Roles } \\
\hline $\begin{array}{l}\text { United Nations Conference on } \\
\text { Environment and Development(UNCED) }\end{array}$ & $\begin{array}{l}\text { Plan and shape strategies and action plans to stop actions that } \\
\text { negatively impact the environment and promote sustainable } \\
\text { development around the world. }\end{array}$ \\
\hline $\begin{array}{l}\text { Organisation for Economic Co-operation } \\
\text { and Development (OECD) }\end{array}$ & $\begin{array}{l}\text { An organisation to help eliminate any obstacles and facilitate trading } \\
\text { activities between member and non-member countries, ensuring that } \\
\text { materials, products, and anything traded are negatively impacting the } \\
\text { environment and humans. }\end{array}$ \\
\hline $\begin{array}{l}\text { United Nations Conferences on Trade and } \\
\text { Development(UNCTAD) }\end{array}$ & $\begin{array}{l}\text { Promoting trade between countries with different social and economic } \\
\text { systems, providing centres for trading activities and development of } \\
\text { government policies and economic groups. }\end{array}$ \\
\hline $\begin{array}{l}\text { United Nations Environment Programme } \\
\text { (UNEP) }\end{array}$ & $\begin{array}{l}\text { It includes global and regional authorities on environmental issues. } \\
\text { Formed as the coordinating agency of environmental policy } \\
\text { development which has been agreed upon and brought environmental } \\
\text { issues that arise to the international community for further action. }\end{array}$ \\
\hline Basel Convention & $\begin{array}{l}\text { An organisation that controls the movement of hazardous waste and } \\
\text { other waste across borders from OECD countries to non-OECD } \\
\text { countries. It is responsible for identifying products and materials that } \\
\text { are harmful and may cause damage to the receiving country. }\end{array}$ \\
\hline
\end{tabular}

Table 1: International Committee Involved in Environmental Movement.

\section{Different Perspective and Definition of Sustainable Development}

At present, the concept of sustainable development has become the most important source of inspiration for the development of effective solid waste management.
The main goal of effective solid waste management is to improve the quality of life of society in various countries, either in developing countries or in developed countries [8]. Most academicians and philosophers from different backgrounds have their own distinctive understanding of the definition of sustainable development (Table 2).

\begin{tabular}{|l|l|l|}
\hline \multicolumn{1}{|c|}{ Perspectives } & Author & \multicolumn{1}{c|}{ Statement } \\
\hline $\begin{array}{l}\text { Protection and enhancement of } \\
\text { environmental impact and solve } \\
\text { problems arising. }\end{array}$ & Wrigley [9] & $\begin{array}{l}\text { "Conservation is greater than individual, group or nation. } \\
\text { Includes scope, scale, important demand that has ever taken } \\
\text { with quick solutions to environmental protection and other } \\
\text { complex problems" }\end{array}$ \\
\hline $\begin{array}{l}\text { Justice to social, environmental } \\
\text { and human life. }\end{array}$ & Leeuw [10] & $\begin{array}{l}\text { "Living in harmony with social and environmental conditions } \\
\text { based on the sense of equality and justice" }\end{array}$ \\
\hline $\begin{array}{l}\text { Realizing the impact of individual } \\
\text { actions on the environment and } \\
\text { finding solutions to problems. }\end{array}$ & Redman [11] & $\begin{array}{l}\text { "Sustainability is an awareness of the relationship between the } \\
\text { world and the implications of our actions. Finding solutions } \\
\text { through innovation approaches, expanding future choices by } \\
\text { practicing environmental care, build institutions that are } \\
\text { constantly studying and cultivating values that promote justice" }\end{array}$ \\
\hline
\end{tabular}

Table 2: Perspectives on Sustainable Development. 
The most commonly used definition is currently adopted from the 1987 edition of the 2008 Brundtland report Our Common Future confirmed during the United Nations General Assembly. Based on the Brundtland report, sustainable development is: "Development that meets the needs of present generation without compromising the ability of future generations to meet their needs" [12].

However, this definition is still common and difficult to translate to face increasingly complex development challenges from time to time. Consequently, the concept of sustainable development has been addressed in Agenda 21 to provide a better explanation for the community. According to Agenda 21, this definition has been submitted by the National Strategy for Sustainable Development by explaining:

"Sustainable development should be built and harmonized with various sectors involving economic, social and environmental policies and plans that operate within a country" [13]. While the definitions and understanding of the sustainable development is distinct, the goal and direction of this sustainable development is same which is to attain a better quality of life.

\section{Understanding Sustainable Development Concept for Solid Waste Management}

The United Nations (UN) and Local Government for Sustainability have made the Triple Bottom Line (TBL) a holistic approach to planning and development (Figure 1). Based on the Liveable Cities Report published in 2007, a sustainable residence should meet environment, economy and social needs. In the context of efficient solid waste management, sustainable development has been taken as the development core through the Triple Bottom Line (TBL) module.

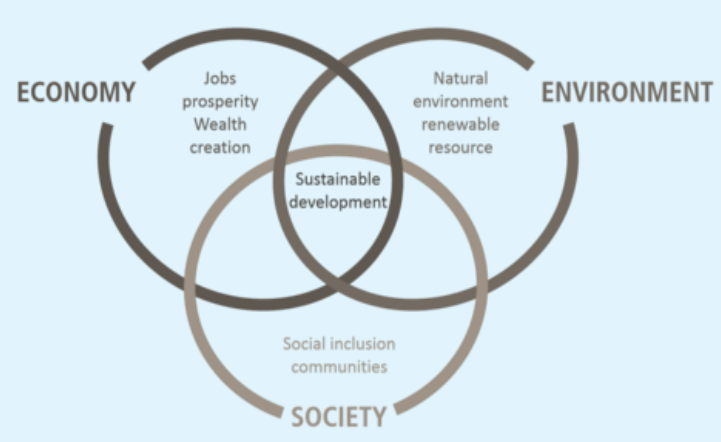

Figure 1: Triple Bottom Line (TBL).
According to the Peace River Regional District solid waste management plan, TBL should be used for decisionmaking, planning and consideration of the implementation of effective solid waste management programs [14]. Sustainable development modules are essential to serve as a guide to efficient solid waste management. The symphony combination between the three (3) components, namely environment, economic and social in solid waste management is a splendid combination for the development of city.

\section{Environmental Context}

The system of solid waste management that been developed should consider environmental context. The practices of solid waste management system that consist of storage, collection, transportation, and disposal should reduce the negative impact on environment. The conservative practice of solid waste management in developing countries like Malaysia has been reported as one of the main contributor in carbon emission to the atmosphere. Disposal of solid waste at landfills should be avoided becauseineffective landfill management will contribute to negative impact on environment, social health and economic development. In most developing countries like Malaysia, landfill is the main disposal method. The current population increase in the city has contributed to a drastic increase in solid waste generated. As a result, many new landfillsare opened to accommodate the solid waste generated. The uncontrolled landfill opening will cause environmental damage as the landfill is one of the causes of water pollution, air pollution, and climate change [15]. Recently, the sanitary landfill has been introduced as an initiative to reduce negative impact of landfill to the environment. However, the maintenance and operation cost of sanitary landfill is very expensive which cannot be afforded by several developing countries and third world countries.

\section{Economical Context}

Referring to the economic context, efficient solid waste management can contribute to the cleanliness and beauty of the city. As a result, clean and beautiful cities can attract foreign tourists to the city. However, merely focus on economic development and neglecting the environment and social development is imbalanced. The phenomenon of rapid increasing of solid waste generated is strongly related to the community lifestyle and economic development. The uncontrolled use of raw materials will have a positive impact on economic development and community needs, but the negative impacts on environmental welfare [16]. Therefore, 
sustainable solid waste management such as solid waste diversion from direct to landfill is very important. Nowadays, the business opportunity of recycling products has earned consumer attention because of its low price. This opportunity has been taken favourably by developed countries to improve the economy while providing efficient solid waste management services.

\section{Sociological Context}

For sociological context, the practices of solid waste management should have the goal of improving the quality of life of society. Theineffective solid waste management is due to a feeble strategy and does not consider the concept of sustainable development. As a result, massive pollutants occur with uncontrolled waste disposal sites [15,17]. For example, organic waste transported to the landfill site will release methane gas. The combination of methane gas and other gases at landfills is very harmful to human health. Humans will be exposed to respiratory illnesses such as bronchitis, and asthma attacks [18]. In addition, cooperation with local community is cricual to achieve sustainability in solid waste management. In fact, local community is the main contributor to the rapid solid waste generated. Information regarding the practices of solid waste management should be delivered effectively to public. The main purpose is to ensure public are not confused and understand their responsibilities in solid waste management system that been practiced [19].

\section{Integrated Solid Waste Management (ISWM)}

\section{An Integration of Sustainable Development Concept with Solid Waste Management:}

Integrated solid waste management (ISWM) is the current solid waste management paradigm that has been widely accepted throughout the developed world. According to Tchobanoglous, et al. ISWM is the term applied to all of activities associated with the management of society's solid waste [20]. The basic goal of ISWM is to manage society's solid waste in a manner that meets public health and environmental concerns. ISWM is increasingly gaining attention in sustainable solid waste management [21]. Moreover, Marshall and Farahbakhsh has emphasised the concept of ISWM is to strike a balance between three (3) dimensions of sustainable development which are environmental effectiveness, social acceptability and economic affordability [22].
Based on the literature reviewed, there are six (6) elements of ISWM such as solid waste generation, collection system, sorting (Material Recovery Facility and Refuse-Derived Fuel), recycling, treatment (Biological and Thermal) and disposal (land filling) Tchobanoglous, et al. [20]. Moreover, Memon has discussed ISWM base on three (3) perspectives which are lifecycle perspective, generation-source perspective and stakeholder/management perspective. According to Marshall and Farahbakhsh, ISWM systems tailored the specific community goals by incorporating stakeholders' perspectives and needs [22]. Besides that, ISWM also consider the local context which from the technical, such as waste characteristics, to the cultural, political, social, environmental, economic and institutional. After that, according to Tchobanoglous, et al. when all the functional elements have been evaluated and all the interfaces and connections between elements have been matches for effectiveness, the suitable techniques, technologies and management programs should be selected [20].

According to Memon, the implementation of ISWM shall contain policies to be enforced, technology as the basic operations, and community activities to raise awareness. Besides that, Marshall and Farahbakhsh has discussed seven (7) significant contexts that have been considered in ISWM such as environmental context, political context, institutional context, social context, cultural context, technical context and economic context (Figure 2) [21,22].

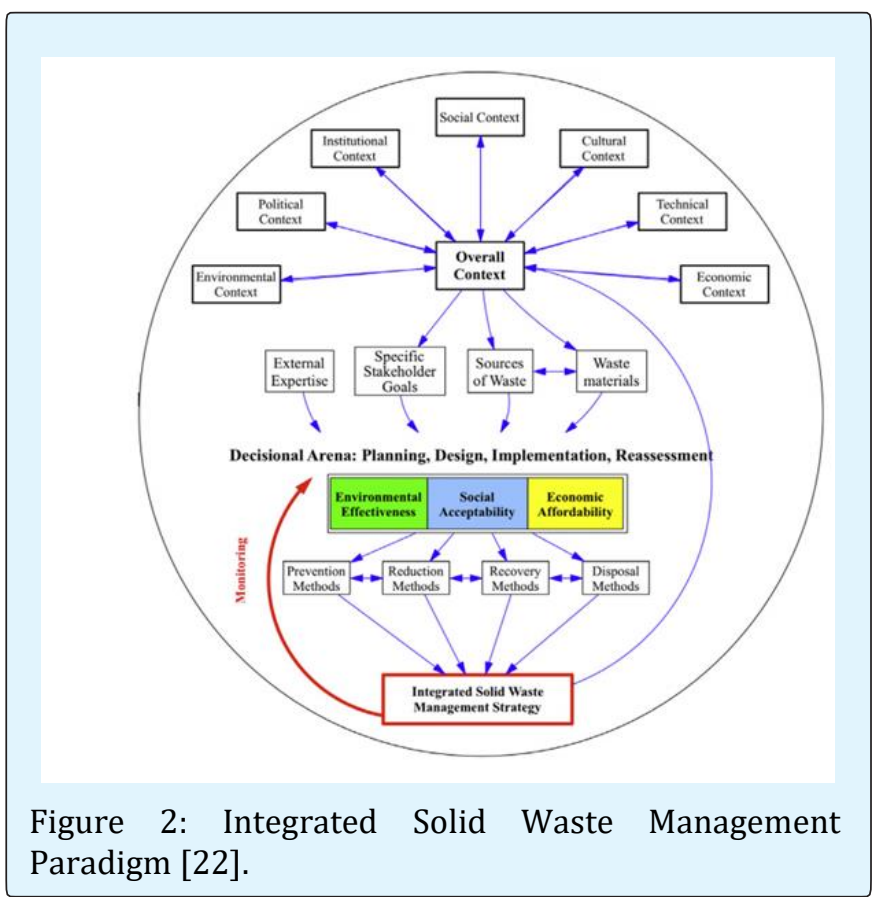




\section{Open Access Journal of Waste Management \& Xenobiotics}

Moreover, previous studies have disclosed that the social, institutional and cultural component is always been ignored in solid waste management system at developing countries [23]. In fact, the structure, functioning, and governance of solid waste management systems are affected by the relationship between central and local governments, the role of party politics in local government administration, and the extent that citizens participate democratically in policy making processes $[24,25]$.

\section{Conclusion}

The application of sustainable development concept in solid waste management is not a new paradigm. It has been practiced by developed countries and its show progression. Therefore, application of sustainable development concepts in solid waste management is a necessity in the scenario to achieve efficient and sustainable solid waste management in developing countries like Malaysia. Indeed, there are challenges and constraints to integrate sustainable development concept and solid waste management at the first place. However, sustainable solid waste management modules can be implemented within the scope of smaller areas first to facilitate their implementation. In small enclaves, the elements involved in the management system are minimal compared to the management system implemented throughout the country. Therefore, the elements involved in management are more easily controlled according to local relevance. Once the program is successfully implemented in a small enclave, a framework or guidance on the implementation of sustainable development for solid waste management should be proposed to other areas or in big enclave.

\section{References}

1. Agamuthu P, Hamid FS, Khidzir K (2009) 'Evolution of solid waste management in Malaysia: Impacts and Implications of the Solid Waste Bill 2007'. Journal of Material Cycles and Waste Management 11(2): 96103.

2. Abas MA (2013) Pelupusan sisa pepejal: kajian sistem kitar semula satu aliran di Pusat Pengajian Sains Matematik dan Sains Komputer (bangunan G31), Universiti Sains, MSc. Thesis, Universiti Sains Malaysia, Geography Section.

3. Abas MA, Seow TW (2014) Municipal Solid Waste Management in Malaysia: An Insight Towards Sustainability, In the proceeding of the $4^{\text {th }}$
International Conference on Human Habitat and Environment, University Kebangsaan Malaysia 18: 192-206.

4. Seow TW, Abas MA (2016) A Review of the Public Policy for Solid Waste Management in Malaysia: An Insight towards Sustainable Solid Waste Management. Aust J Basic \& Appl Sci 10(1): 58-64.

5. Shulman VL (2011) Introduction to Waste Management: Trends in Waste Management, In Waste: A Handbook for Management, Letcher TM, et al. (Eds.), Amsterdam: Elsevier, Netherlands.

6. UN: United Nations (2010) History of the United Nations, pp: 1-3.

7. UNEP: United Nations Environment Programme (2012) Waste, Division of Technology, Industry and Economy, Sustainable Consumption, New York: United Nation.

8. Baud I, Grafakos S, Hordijk M, Post J (2001) Quality of Life and Alliances in Solid Waste Management: Contributions to Urban Sustainable Development. Cities 18(1): 3-12.

9. Wrigley JA (2006) Global Sustainability, Arizona: ASU Global Institute, USA.

10. Leeuw SV (2006) Sustainability. Arizona: Earth scan.

11. Redman CL (2007) Environment and Development: Sustainability Science, Victoria, Royal Road University, Canada.

12. WCED: World Commission on Environment and Development (1987) Our Common Future, Oxford: Oxford University Press.

13. OECD: Organisation for Economic Cooperation and Development (2006) Good Practices in the National Sustainable Development Strategies of OECD Countries, Paris: OECD.

14. Peace River Regional District (2008) Solid Waste Management Plan. Burnaby, Canada: Earth Tech.

15. Kathiravale S, MuhdYunus MN (2008) 'Waste to Wealth'. American Economy Journal 6: 359-371.

16. Cointreau S (2006) Occupational and Environmental Health Issues of Solid Waste Management: Special Emphasis on Middle and Lower Income Countries, 


\section{Open Access Journal of Waste Management \& Xenobiotics}

Report for Waste Management Unit, World Health Organisation (WHO), and European Countries.

17. Pandey PC, Sharma LK, Nathawat MS (2012) Geospatial Strategy for Sustainable Management of Municipal Solid Waste for Growing Urban Environment. Environment Monitoring and Assessment 184(4): 2419-2431.

18. Kampa M, Castanas E (2008) Human Health Effects of Air Pollution. Environmental Pollution 151(2): 362 367.

19. Tanaka M (2007) Waste Management for a Sustainable Society. Journal Material Cycles and Waste Management 9(1): 2-6.

20. Tchobanoglous G, Theisen H, Vigil SA (1993) Integrated Solid Waste Management: Engineering Principles and Management Issues, Singapore: McGraw-Hill.

21. Memon MA (2010) Integrated Solid Waste Management Base on the 3R Approach. Journal of Material Cycles and Waste Management 12(1): 30-40.
22. Marshall RE, Farahbakhsh K (2013) System Approaches to Integrated Solid Waste Management in Developing Countries. Waste Management 33(4): 988-1003.

23. Abas MA, Wee ST, Chen GK, Mohamed S (2018) The Constraints of Good Governance Practice in National Solid Waste Management Policy (NSWMP) Implementation in Malaysia. Advanced Science Letters, 24(6): 4704-4709.

24. Schübeler P (1996) Conceptual Framework for Municipal Solid Waste Management in Low-income Countries, Gallen, Switzerland: Swiss Centre for Development Cooperation in Technology and Management (SKAT).

25. CGSS: Centre for Global Sustainability Studies (2009) USM-APEX Sustainability Fact Sheet. Pulau Pinang: University Sains Malaysia. 